\title{
Photosynthetic responses of corals Mussismilia harttii (Verrill, 1867) from turbid waters to changes in temperature and presence/absence of light
}

\author{
Ana Paula Martins Winter ${ }^{*}$, Ricardo Moreira Chaloub ${ }^{1}$, Gustavo Adolpho Santos Duarte ${ }^{l}$, Clovis \\ Barreira e Castro ${ }^{l}$
}

\author{
${ }^{1}$ Universidade Federal do Rio de Janeiro - Museu Nacional. \\ (Quinta da Boa Vista - São Cristóvão, Rio de Janeiro - RJ, 20940-040) \\ *Corresponding author: ana_winter@hotmail.com
}

\section{ABstract}

Responses of corals to climate change stresses are species and locality specific. As light is an important component of temperature-induced stresses, we experimentally tested the responses of a turbid water coral, Mussismilia harttii, to changes in temperature in the presence and absence of light. Chlorophyll fluorescence parameters were measured using a divingPAM. Experiments were carried out at distinct temperatures. Polyps were kept in the dark or were continuously exposed to $300 \mu \mathrm{mol}$ photons $\mathrm{m}^{-2} \cdot \mathrm{s}^{-1}$ irradiance. No visible bleaching of coral samples was seen in temperatures between 26.5 and $35.0{ }^{\circ} \mathrm{C}$, but most polyps at higher temperatures showed signs of tissue necrosis. There was a reduction of $F_{\mathrm{v}} / F_{\mathrm{m}}$ as temperature increased, with a further drop in the presence of light, indicating a synergistic effect of these factors. We suggest that the photodamage to $M$. harttii endosymbionts triggered by temperatures of $33.0{ }^{\circ} \mathrm{C}$ and $35.0{ }^{\circ} \mathrm{C}$ results from a decline of the repair process, as well as the effect of light on the PSII. Recovery data for polyps kept in $31.0{ }^{\circ} \mathrm{C}$ showed that this temperature (depending on time of exposure) seems to be borderline; temperatures higher than $31.0{ }^{\circ} \mathrm{C}$ lead to long-term damage or death of $M$. harttii.

Descriptors: Climate changes, Coral, Photosynthesis, Temperature, Chlorophyll fluorescence, Diving-PAM.

\section{RESUMo}

Respostas de corais a estresses de mudanças de temperatura são específicas e dependem também da localidade. Como a luz é um componente importante dos estresses induzidos pela temperatura, testamos experimentalmente as respostas de Mussismilia hartii, coral originário de águas turvas, a mudanças de temperatura, na presença e ausência de luz. Parâmetros de fluorescência da clorofila foram medidos com Diving-PAM. Os experimentos foram mantidos a temperaturas distintas. Os pólipos permaneceram no escuro ou foram continuamente expostos a $300 \mu \mathrm{mol}$ photons $\mathrm{m}^{-2} \cdot \mathrm{s}^{-1}$ de irradiância. Nenhum branqueamento visível foi observado entre as temperaturas de 26,5 a $35,0{ }^{\circ} \mathrm{C}$, mas a maioria dos pólipos expostos a temperaturas elevadas mostraram sinais de necrose do tecido. Houve uma redução de $F_{\mathrm{v}} / F_{\mathrm{m}}$ em resposta ao aumento da temperatura, que foi exacerbada na presença de luz, indicando um efeito sinergético desses fatores. Sugerimos que o fotodano sofrido pelos endossimbiontes de $M$. harttii, desencadeados nas temperaturas de 33,0 e $35,0{ }^{\circ} \mathrm{C}$, resultou de uma diminuição do processo de reparação, assim como o efeito da luz sobre o PSII. A recuperação de pólipos mantidos a $31,0{ }^{\circ} \mathrm{C}$ indicou que essa temperatura parece ser limítrofe (dependendo do tempo de exposição); temperaturas acima de $31,0{ }^{\circ} \mathrm{C}$ levaram a danos irreversíveis ou morte de $M$. harttii.

Descritores: Mudanças climáticas, Coral, Fotossíntese, Temperatura, Fluorescência da clorofila, Diving-PAM. 


\section{INTRODUCTION}

Climate change is already affecting coral reefs around the globe (BUDDEMEIER et al., 2004). Shallowwater reef-building corals host single-celled microalgae (zooxanthellae) that live in their body tissues. Stresses can interfere in this symbiotic relationship. "Bleaching" describes the loss of symbiotic algae or their pigments by the coral. Bleaching is a stress response to several oceanographic parameters, such as high or low temperatures, intense light, changes in salinity, or other physical or chemical stresses like cyanide and herbicides. High seawater temperature is one of the main concerns associated with climate change and reef corals (HOEGH-GULDBERG, 1999; SAXBY et al., 2003). However, the temperature leading to bleaching is not an absolute value; it is associated with other variables, especially light (MUMBY et al., 2001). The difference between "normal" local temperatures and stress temperatures seems to be more important than the latter itself. However, localities where temperatures are usually higher seem to be more vulnerable to bleaching (FITT et al., 2001). According to SAXBY et al. (2003), apparently, coral reefs exposed to low temperatures respond in the same way as corals exposed to high temperatures, including decrease in photosynthetic efficiency $\left(F_{\mathrm{v}} / F_{\mathrm{m}}\right)$, decrease in Symbiodinium rate, besides photodamage, bleaching and increased mortality, suggesting there is a common mechanism.

Regarding zooxanthellae, there are different resistance reports to higher temperatures even within the same zooxanthellae clade in different localities and coral species (see VAN OPPEN et al., 2009). Therefore, responses of corals to climate change are species and locality specific.

Southwestern Atlantic reefs are unique, with a relatively low coral diversity (only 18 Scleractinia species), but with high endemism (CASTRO; PIRES, 2001; NUNES et al., 2008). Among the six endemic species in Brazil is Mussismilia harttii (VERRILL, 1868), distributed from the State of Rio Grande do Norte to the state of Espírito Santo, in addition to the islands of Fernando de Noronha and Atol das Rocas (LEÃO et al., 2008). The reef-builder corals of Brazil coexist with a highly terrigenous environment. Excessive sedimentation is one of the main threats to coral reefs. There is a variation in tolerance to sedimentation among corals species (PHILIPP; FABRICIUS, 2003; ROGERS, 1990). M. harttii presents large polyps suggesting greater resistance to environmental stresses, having developed a more efficient mechanism for cleaning themselves of sediment (ROGERS, 1990; LEÃO et al., 2003). Almost all reefs located on the continental shelf are immersed in turbid waters (LEÃO; DOMINGUEZ, 2000). Therefore, studies from other oceans do not provide adequate support to understanding ecological processes and responses to climate change in this remarkable environment.

Large-scale bleaching has been reported in turbid reefs of the Southwestern Atlantic since the 1990s. Here, we use the categories of bleaching indicated in OLIVER et al., 2009. In the summer of 1994, severe bleaching was reported in reef (Abrolhos, $18^{\circ} \mathrm{S}-\mathrm{CASTRO}$; PIRES, 1999 ) and non-reef areas (Canal de São Sebastião, $24^{\circ} \mathrm{S}$ - MIGOTTO, 1997). Both reports associated the events with temperature anomalies and, in the reef area, to higher temperatures occurring in a longer daylight period (summer solstice). In the 1998 summer-autumn season, temperature-related severe bleaching events were reported in eastern Brazil (12-13 S - LEÃO et al., 2003; 2008). Mild to moderate bleaching was reported in 2002, 2003, and 2005 in eastern (12-18 S - LEÃO et al., 2008) and northeastern Brazil $\left(9^{\circ} \mathrm{S}-\right.$ MINISTÉRIO DO MEIO AMBIENTE, 2006). Although there are discrepancies in data acquisition (for instance, see types of registered bleaching [weak and strong] grouped together by LEÃO et al. (2008): Figure 6, and for assessment of the extent of coral bleaching, see SEIBECK et al. (2006), it is evident that bleaching phenomena are frequent in these reefs. However, unlike reefs in most other oceans, no mass mortality of scleractinian corals has been associated so far with bleaching events in the Southwestern Atlantic.

Turbidity in Southwestern coral reefs may be affecting responses of their corals to temperature changes. Corals in these environments are adapted to low-light conditions. As light is an important component of temperature-induced stresses, we experimentally tested the responses of an endemic coral from a turbid water area, $M$. harttii through measurements of variation in photochemical efficiency $\left(F_{\mathrm{v}} / F_{\mathrm{m}}\right)$, to changes in temperature in the presence and absence of light, as well as the synergistic effects between these parameters.

\section{MATERIAL AND METHODS}

\section{Biological Material}

About 120 coral polyps of the scleractinian coral Mussismilia harttii were collected from 2.5-4.0 m depth, with a branch collected from each colony, near "Recife de Fora” (16 $\left.25^{\prime} 06.67^{\prime \prime} \mathrm{S}, 039^{\circ} 00^{\prime} 05.58^{\prime \prime} \mathrm{W}\right)$, State of Bahia, 
Brazil, in November 2008. Corals were transported in seawater at circa $26.5^{\circ} \mathrm{C}$ (ambient seawater temperature). Subsequently, they were transferred to a semi-open seawater system consisting of a 1,000 L tank under natural daylight, which varied between 50 and $180 \mu \mathrm{mol} \cdot \mathrm{m}^{-2} \cdot \mathrm{s}^{-1}$. Due to logistic constraints, all polyps were collected in a single day and kept under these conditions for 5-12 days for acclimation (PHILIPP; FABRICIUS, 2003; SAXBAY et al., 2003; WINTERS et al., 2009; KUGURO et al., 2010; PUTNAM; EDMUNDS, 2011) prior to the experiments. They were monitored visually once a day and the $F_{\mathrm{v}} / F_{\mathrm{m}}$ verified prior to the start of the experiment in order to demonstrate the health of the samples.

\section{Chlorophyll-a Fluorescence Measurements}

Chlorophyll fluorescence parameters were measured using a pulse amplitude modulated fluorometer (divingPAM, Walz, Effeldricht, Germany) and an $8 \mathrm{~mm}$ standard glass-fiber optic probe (Walz, Effeldricht, Germany), which was positioned above the oral disk of polyps. After dark adaptation for $20 \mathrm{~min}$, initial fluorescence $\left(F_{0}\right)$ was measured using a weak probe of modulated light $(<1 \mu$ mol photons.m$\left.{ }^{2} \cdot \mathrm{s}^{-1}\right)$ and maximum fluorescence $\left(F_{\mathrm{m}}\right)$ was estimated with a saturating pulse ( $800 \mathrm{~ms}$ pulse of $6,000 \mu \mathrm{mol}$ photons.m$\left.{ }^{2} \cdot \mathrm{s}^{-1}\right)$. Variable fluorescence $\left(F_{\mathrm{v}}\right)$ was calculated from $F_{\mathrm{m}}-F_{0}$ and the maximum quantum efficiency of Photosystem II (PSII) photochemistry was obtained from the ratio $F_{\mathrm{v}} / F_{\mathrm{m}}$. Samples were acclimated to an irradiance of $187 \mu \mathrm{mol} . \mathrm{m}^{-2} \cdot \mathrm{s}^{-1}$ for 5 min during measurements of a light induction curve. At the end of this 5-min curve, rETR (relative electron transport rate) measurements were obtained through the application of a series of saturation pulses under increasing irradiance (121, $187,262,393,535,817,1205$, and $1820 \mu$ mol photons.m${ }^{2} \cdot \mathrm{S}^{-1}$ ) in the form of a rapid light curve (RALPH et al., 1999; RALPH; GADEMANN, 2005). Light-adapted fluorescence yield $\left(F_{\mathrm{s}}\right)$ and maximum light-adapted fluorescence yield $\left(F_{\mathrm{m}}{ }^{\prime}\right)$ were determined at the end of a $10 \mathrm{sec}$ period at each irradiance level, and the effective quantum yield of PSII as a function of irradiance was calculated from $F_{\mathrm{PSII}}=\left(F_{\mathrm{m}}\right.$ $\left.F_{\mathrm{s}}\right) / F_{\mathrm{m}}$. The proportion of open PSII reaction centers under each actinic light was determined by the photochemical quenching coefficient, $\mathrm{qP}=\left(F_{\mathrm{m}}{ }-F_{\mathrm{s}}\right) /\left(F_{\mathrm{m}}-F_{0}\right)$, and the nonphotochemical Stern-Volmer coefficient (NPQ) calculated from $\left(F_{\mathrm{m}}-F_{\mathrm{m}}{ }_{\mathrm{m}}\right) / F_{\mathrm{m}}$. . $\mathrm{ETR}$ was calculated as $F_{\mathrm{PSII}}$ PAR $0.5 \mathrm{Ar}$ (GENTY et al., 1989), where the fraction of absorbed light (Ar) was presumed to be 1, due to the technical difficulty of measuring this parameter, and the figure 0.5 is used as an invariable number (assuming all light energy is absorbed by chlorophyll and that the incident light quantum of PSI and PSII is equal). The Diving-PAM settings were: measuring light 2 , saturating intensity 8 , saturating width $0.8 \mathrm{~s}$, gain 2 and damping 2 .

\section{EXPERIMENTAL PRotocol}

Given the elapsed time for fluorescence measurements at each temperature, the polyps remained in the dark at $26.5{ }^{\circ} \mathrm{C}$ from 20 to $60 \mathrm{~min}$ prior to the beginning of the experiments. This incubation time was sufficient to promote a dark adaptation of the samples and did not influence the physiological response, since distinct times used for dark adaptation are found in the literature. For instance, 20 and $120 \mathrm{~min}$ were used for Pocillopora damicornis (JONES et al., 1998; JONES et al., 2000; FRISCH et al., 2007), and a dark adaptation of from 20 to 60 min was used for calculating $F_{\mathrm{v}} / F_{\mathrm{m}}$ in other coral species (BROWN et al., 1999; WARNER et al., 1999; JONES et al., 2000; JONES; HOEGH-GULDBERG, 2001). Experiments were carried out in open-topped glass aquaria kept at distinct temperatures (26.5 [control], 29.0, 31.0, 33.0, and $35.0^{\circ} \mathrm{C}$ ). Temperatures were stabilized by immersion heaters (Sarlo Pet 200-300 W) monitored and adjusted using automatic controllers (Full Gauge MT543Ri Plus). Additionally, each aquarium was immersed in a water bath, which received cold water whenever necessary for cooling the system. Temperatures were recorded in a laptop through an USB interface (Sitrad Conv 32), and varied, at most, $0.1{ }^{\circ} \mathrm{C}$ throughout the entire experiment. Due to logistic constraints, only two polyps from different colonies were placed in each aquarium, fixed in sand: one remained in the dark (covered by an aluminum cup) and the other was continuously exposed to $300 \mu$ mol photons.m${ }^{2} \cdot \mathrm{s}^{-1}$ irradiance, provided by four fluorescent bulbs (Philips T5 HO Activiva Active $54 \mathrm{~W}$ ) suspended above the tanks. Photosynthetically active radiation (PAR) was measured with a Fiber Quantum Sensor connected to the DivingPAM. Chlorophyll-a fluorescence measurements were taken every $95 \mathrm{~min}$ for $285 \mathrm{~min}$. After measuring $F_{0}$ and $F_{\mathrm{m}}$, samples were light activated $\left(187 \mu \mathrm{mol} . \mathrm{m}^{2} . \mathrm{s}^{1}\right)$ for $3-5$ min and rETR measurements were obtained from rapid light curves, as described above. Six independent runs (with new polyps and new seawater) of the experiment were carried out, each being considered a replicate. At the end of each run, polyps were moved to larger aquaria (circa $26.5{ }^{\circ} \mathrm{C}$ and circa $\left.50 \mu \mathrm{mol} \cdot \mathrm{m}^{-2} \cdot \mathrm{s}^{-1}\right)$. Twenty-four hours after the experiment, the maximum quantum efficiency of PSII $\left(F_{\mathrm{v}} / F_{\mathrm{m}}\right)$ was estimated to evaluate recovery. 


\section{Statistical Analysis}

Data were tested for normality using the KolmogorovSmirnov's test (K-S) and for homoscedasticity of variances using Levene's test. Repeated measures analyses of variance (ANOVA) were used to test if the maximum quantum yield of PSII $\left(F_{v} / F_{\mathrm{m}}\right)$, the photosynthetic efficiencies $(\alpha)$, the maximum relative electron transport rate (rETRmáx), and the minimum saturating irradiance $\left(\mathrm{E}_{\mathrm{k}}\right)$ were affected by exposure to different temperatures, light conditions (dark/light), and time span of exposure to these different conditions. ANOVA was used even when samples were heteroscedastic because, if the size of the sample is equal for all treatments, the analysis is robust even with considerable heterogeneity (GLASS et al., 1972 apud ZAR, 1999). Tukey's (HSD) post hoc test was applied for ANOVAs that indicated a significant probability of rejection of the null hypothesis $(p<0.05)$. Bifactorial ANOVA was used to test recovery $24 \mathrm{~h}$ after the experiment. Repeated measures ANOVAs were carried out in R, version 2.10 (http://www.rproject.org/); all other tests were carried out with Statistica 7.0 (StatSoft). Graphs were prepared with SigmaPlot, version 10.0 or Microsoft Excel 2007.

All data for $F_{\mathrm{m}}, F_{\mathrm{v}} / F_{\mathrm{m}}, \mathrm{rETR}_{\max }, \alpha$ and $\mathrm{E}_{\mathrm{k}}$ were normal (Kolmogorov-Smirnov, $p>0.20$ ). Levene's test showed heteroscedastic variances for $F_{\mathrm{m}}\left(\mathrm{F}_{4,30}=2,423\right), F_{\mathrm{v}} / F_{\mathrm{m}}$ $\left(\mathrm{F}_{4,30}=2.235\right), \mathrm{rETR}_{\max }\left(\mathrm{F}_{4,30}=1.551\right)$ and $\mathrm{E}_{\mathrm{k}}\left(\mathrm{F}_{4,30}=1.314\right.$; $p=0.142$ ) except for $\alpha$ that showed homoscedastic variances $\left(\mathrm{F}_{4,30}=1.289 ; p=0.134\right)$. Sample size was equal.

\section{RESULTS}

Repeated measures ANOVA with $F_{\mathrm{m}}$ showed that most variables tested (time, temperature, polyps, irradiance (dark/light), time+temperature and time+irradiance) presented highly significant differences $(p<0.001$; Table 1). The results for $F_{0}$ were more stable in all treatments, so the $F_{\mathrm{v}}$ variation is related to changes in $F_{\mathrm{m}}$ (Figure 1).

\section{Maximum Quantum Yield of Photosystem II (Fv/FM) FOR DARK-ADAPTED SAMPLES}

In polyps kept in the dark, there was a decrease in $F_{\mathrm{v}} / F_{\mathrm{m}}$ of approximately $10-21 \%$ in the initial $95 \mathrm{~min}$ of the experiment at temperatures between 26.5 and $31.0^{\circ} \mathrm{C}$, with a subsequent stabilization (Figure 2A). At $33.0^{\circ} \mathrm{C}$, there was a continuous drop in $F_{\mathrm{v}} / F_{\mathrm{m}}$ values. Polyps maintained at $35.0^{\circ} \mathrm{C}$ showed a strong initial decrease (circa $57 \%$ after $95 \mathrm{~min}$ ), which continued throughout the experiment and reached a $67 \%$ decrease at the end of the experiment ( $285 \mathrm{~min}$ ). Comparatively, polyps exposed to light showed an even stronger effect of increased temperatures on the maximum quantum yield (Figure 2B), suggesting again a synergy of temperature and light. Furthermore, polyps maintained at $33.0^{\circ} \mathrm{C}$ differed from those kept at 31.0 ${ }^{\circ} \mathrm{C}$ only at the end of the experiment (with light), suggesting an added effect due to time of exposure.

In spite of a gradational decrease in photochemical efficiency, no bleaching was observed in $M$. harttii kept at temperatures between 26.5 and $35.0{ }^{\circ} \mathrm{C}$ throughout the experiment (circa $5 \mathrm{~h}$ ), either in the dark or the light. However, polyps seemed to present an initial tissue necrosis as soon as $95 \mathrm{~min}$ after exposure to light and temperatures of $35.0^{\circ} \mathrm{C}$ (Figure 3 ), a condition also observed in the dark treatment at this temperature (Figure 4 ).

Repeated measures ANOVA with $F_{\mathrm{v}} / F_{\mathrm{m}}$ showed again that most variables tested (time, temperature, polyps, irradiance (dark/light) and time+irradiance showed highly significant differences $(p<0.001$; Table 1$)$.

\section{FLUORESCENCE YIELD $(F)$ AND MAXIMUM FLUORESCENCE YIELD OF LIGHT-ADAPTED SAMPLES $\left(F{ }^{\prime}{ }\right)$}

Rapid light curves (RLC) at the beginning of the experiments (polyps of all treatments kept in the dark at $26.5^{\circ} \mathrm{C}$ ) showed that $F$ increased with irradiance intensity until the sixth step of the RLC (seventh light pulse), nearly stabilizing afterwards (Figure 5A). A similar, but opposite, behavior was seen with $F^{\prime}$, with its values decreasing and coming closer those of $F$ (Figure 5A).

Polyps incubated in the dark at different temperatures showed a decrease in the difference between $F$ and $F_{\mathrm{m}}$, especially with increasing temperatures (rows in Figure 5). Subsequent (time) measurements showed little variation (columns in Figure 5). Polyps incubated in light behaved similarly, but $F$ values at different temperatures were essentially the same, while $F_{\mathrm{m}}^{\prime}$ values presented an increasing drop (except at $35.0{ }^{\circ} \mathrm{C}$, when they became equal to $F$ ) (Figure 6).

RELATIVE ELECTRON TRANSPORT RATES (RETR), MAXIMUM RELATIVE ELECTRON TRANSPORT RATES $\left(\right.$ RETR $\left._{\text {MAX }}\right)$, PHOTOSYNTHETIC EFFICIENCIES $(\alpha$ - PHOTOSYNTHETIC RATE IN LIGHT-LIMITED REGION OF RAPID LIGHT CURVES), AND MINIMUM SATURATING IRRADIANCES $E_{\mathrm{K}}$ )

Rapid Light Curves (RLCs) at the beginning of the experiments $(\mathrm{t} 0$; all treatments in the dark and at 26.5 
Table 1. Repeated measures ANOVA with $F_{\mathrm{m}}, F_{\mathrm{v}} / F_{\mathrm{m}}, \mathrm{rETR}_{\max }, \alpha$ and $\mathrm{E}_{\mathrm{k}}$ established that most variables tested (time, temperature, polyps, irradiance, time+temperature, time+irradiance) showed highly significant differences $(p<0.001)$, where $p=$ significance level, $F=F$-value, $d f=$ degrees of freedom.

\begin{tabular}{|c|c|c|c|c|c|c|c|c|c|c|}
\hline & \multicolumn{2}{|c|}{$\mathrm{F}_{\mathrm{m}}$} & \multicolumn{2}{|c|}{$\mathrm{F}_{\mathrm{v}} / \mathrm{F}_{\mathrm{m}}$} & \multicolumn{2}{|c|}{ rETR $_{\text {max }}$} & \multicolumn{2}{|c|}{$\alpha$} & \multicolumn{2}{|c|}{ Ek } \\
\hline & $\mathrm{F}$ & $\mathrm{df}$ & $\mathrm{F}$ & $\mathrm{df}$ & $\mathrm{F}$ & $\mathrm{df}$ & $\mathrm{F}$ & $\mathrm{df}$ & $\mathrm{F}$ & $\mathrm{df}$ \\
\hline Time & 54.4286 & 3 & 431.6621 & 3 & 31.0487 & 3 & 278.8981 & 3 & 49.3714 & 3 \\
\hline Temperature & 10.5141 & 4 & 252.9198 & 4 & 186.8456 & 4 & 301.5586 & 4 & 9.4996 & 3 \\
\hline Polyps & 9.5395 & 53 & 4.3389 & 53 & 11.9606 & 53 & 5.2122 & 53 & 6.5769 & 42 \\
\hline Irradiance & 6.6431 & 1 & 372.4152 & 1 & 45.1186 & 1 & 310.6992 & 1 & 90.8872 & 1 \\
\hline Time+temperature & 3.2748 & 12 & 34.2752 & 12 & 19.1595 & 12 & 32.1787 & 12 & 1.0223 & 9 \\
\hline Time+irradiance & 16.3931 & 3 & 39.119 & 3 & 0.8192 & 3 & 26.9274 & 3 & 19.0477 & 3 \\
\hline
\end{tabular}

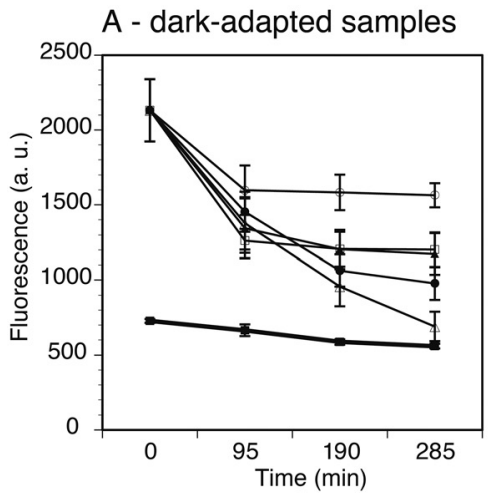

B - light-adapted samples

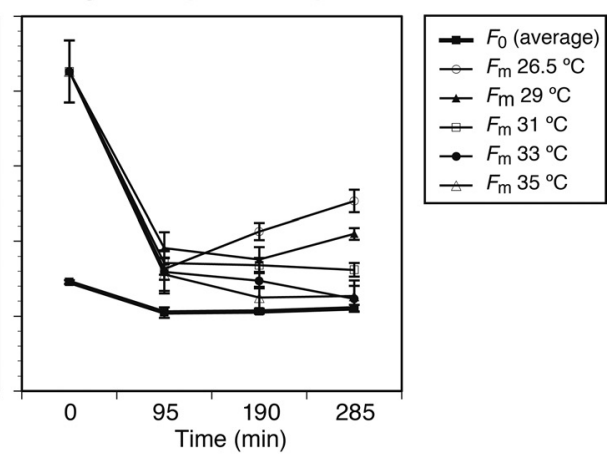

Figure 1. Minimum $\left(F_{0}\right)$ and maximum $\left(F_{\mathrm{m}}\right)$ fluorescence values of Mussismilia harttii polyps maintained at different temperatures (26.5 [control], $29,31,33$, and $35^{\circ} \mathrm{C}$ ) and different experimental periods (zero, 95, 190, and $285 \mathrm{~min}$ ). (A) kept in the dark; (B) exposed to light (300 mmol photons $\left.\mathrm{m}^{-2} \cdot \mathrm{s}^{-1}\right) \cdot F_{0}$ presented as an average for all temperatures; $\mathrm{n}=30 ; \mathrm{n}$ for $F_{\mathrm{m}}=6$. Bars show standard errors.

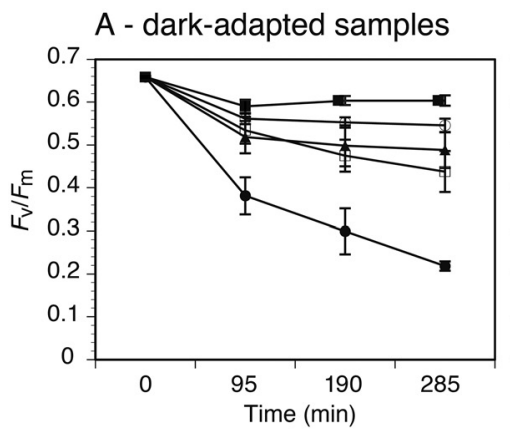

\section{B - light-adapted samples}

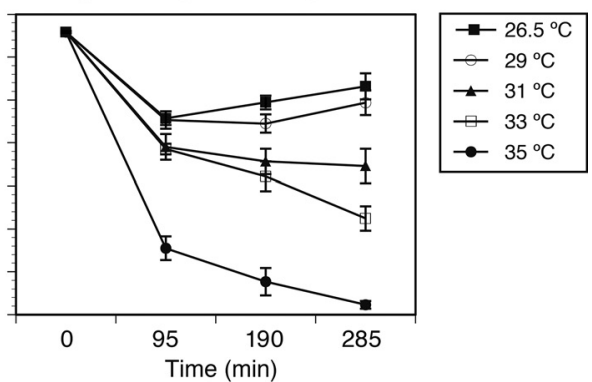

Figure 2. Maximum quantum yield $\left(F_{\mathrm{v}} / F_{\mathrm{m}}\right)$ of Mussismilia harttii polyps maintained at different temperatures (26.5 [control], $29,31,33$, and $\left.35{ }^{\circ} \mathrm{C}\right)$ and different experimental periods (zero, 95, 190, and $285 \mathrm{~min}$ ). (A) kept in the dark; (B) exposed to light (300 $\left.\mathrm{mmol}^{\mathrm{photons}} \mathrm{m}^{-2} . \mathrm{s}^{-1}\right)$. Bars show standard errors; $\mathrm{n}=6$.

$\left.{ }^{\circ} \mathrm{C}\right)$ show an increase in rETR as light intensity increased and a small decline under irradiances higher than 817 $\mu$ mol photons. $\mathrm{m}^{-2} \cdot \mathrm{s}^{-1}$ (Figures 7-8). In the dark-adapted samples, RLCs of polyps incubated at temperatures up to $33.0{ }^{\circ} \mathrm{C}$ did not show large departures from this baseline pre-experiment curve, with a slight increase in $\mathrm{rETR}_{\max }$ (except at $33.0^{\circ} \mathrm{C}$ after $235 \mathrm{~min}$ ). Polyps incubated at $35.0^{\circ} \mathrm{C}$, on the other hand, showed a large departure from the baseline curve at all times, with significant decreases in $\mathrm{rETR}_{\max }$ and $\alpha$ (initial slope of the rapid light curve before the onset of saturation) (Figure 7). In lightadapted samples, large departures from the baseline curve can be seen at temperatures equal to or higher than 31.0 ${ }^{\circ} \mathrm{C}$ (Figure 8). In the light-adapted samples, there was a decrease of $\mathrm{rETR}_{\max }$ and $\alpha$ after incubation started at 31.0 ${ }^{\circ} \mathrm{C}$, which remained constant during the entire experiment 


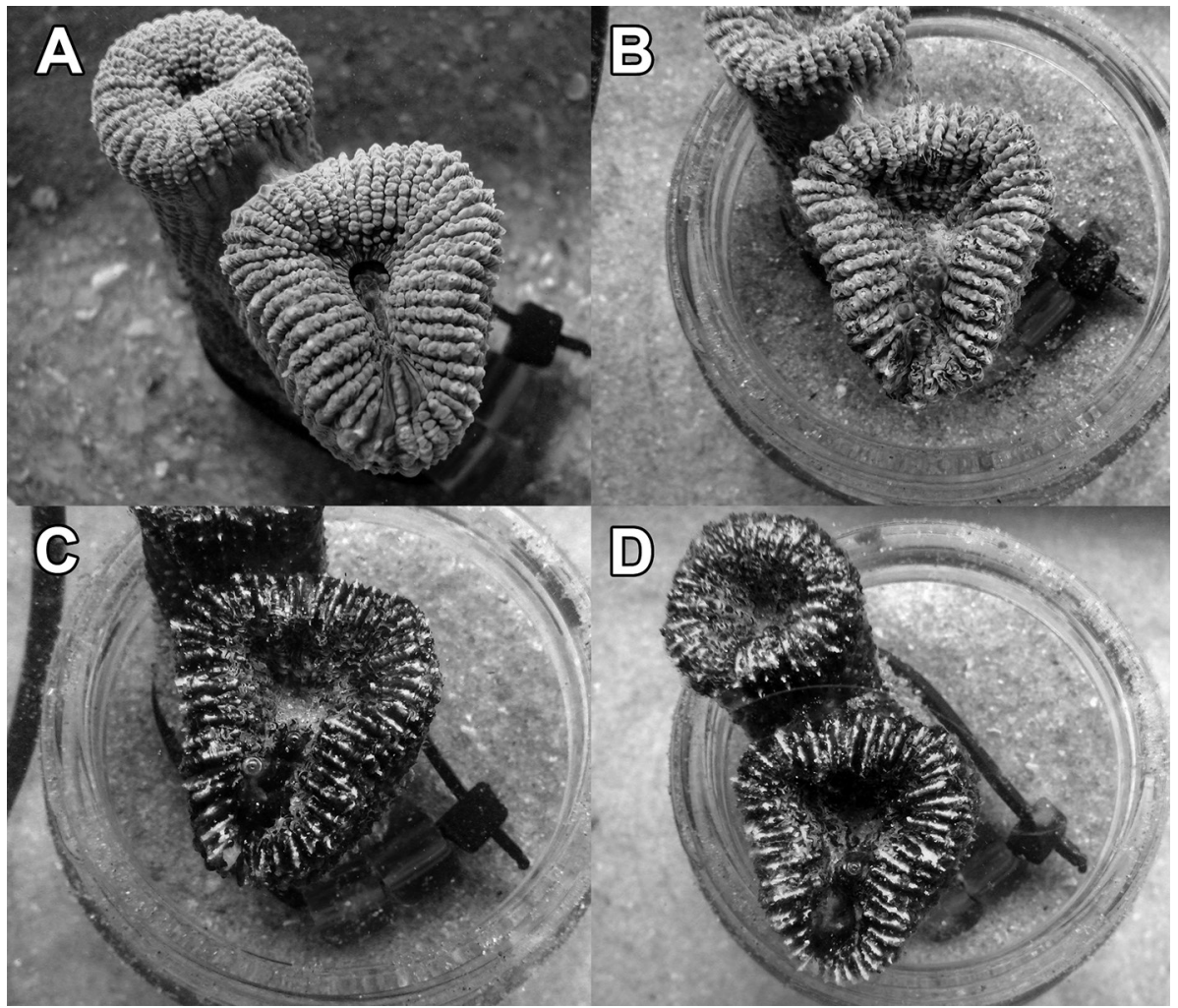

Figure 3. Polyp of Mussismilia harttii kept at $35.0^{\circ} \mathrm{C}$ with light $\left(300 \mathrm{mmol}\right.$ of photons. $\left.\mathrm{m}^{-2} \cdot \mathrm{s}^{-1}\right)$ : $\mathrm{A}=$ before exposure; $\mathrm{B}=$ after $95 \mathrm{~min} ; \mathrm{C}=$ after $190 \mathrm{~min}$; and $\mathrm{D}=$ after $285 \mathrm{~min}$.

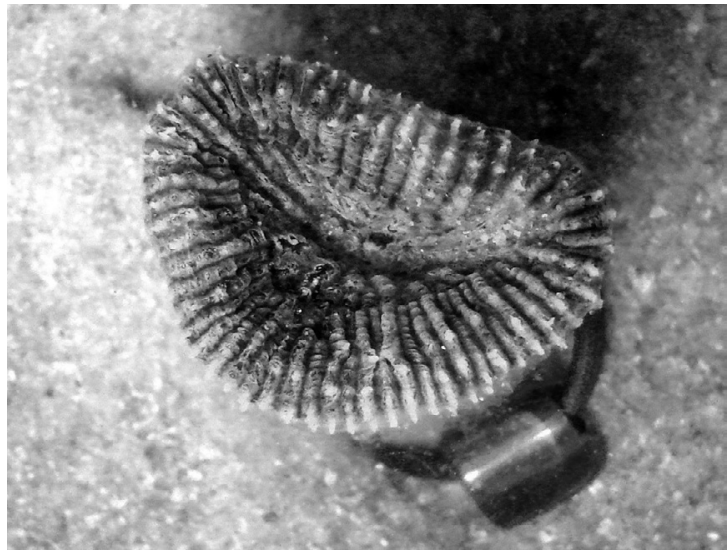

Figure 4. Polyp of Mussismilia harttii after 285 min maintained at $35.0{ }^{\circ} \mathrm{C}$ in the dark.

(Figure 8). This decrease was even more pronounced at higher temperatures, with an added time effect, which resulted in significantly different values of $\mathrm{rETR}_{\max }$ and $\alpha$. Dark-adapted polyps incubated at $35.0^{\circ} \mathrm{C}$ presented a severe decrease in photosynthetic activity $(p<0.03)$, with circa $63 \%$ reduction after $285 \mathrm{~min}$ of experiment (Figure 7). Light-adapted polyps incubated at this temperature resulted in an absence of photosynthetic activities after 95 min (Figure 8). Light-adapted polyps presented smaller $\alpha$ than similar dark-adapted polyps in all treatments.

Repeated measures ANOVA with $\mathrm{rETR}_{\max }$ showed that most variables tested (time, temperature, polyps, irradiance [dark/light], time+temperature) showed highly significant differences $(p<0.001$; Table 1$)$.

Repeated measures ANOVA with $\alpha$ showed that most variables tested (time, temperature, polyps, irradiance (dark/light), time+temperature, and time+irradiance) showed highly significant differences $(p<0.001$; Table 1$)$.

Minimum saturating irradiances $\left(\mathrm{E}_{\mathrm{k}}\right)$ were larger in lightthan in dark-adapted polyps throughout the experiment. Control polyps (maintained at $26.5{ }^{\circ} \mathrm{C}$ ) did not show significant differences along the experiment (Tukey's HSD). However, Tukey's HSD post-Hoc tests showed differences between the beginning of the experiment (all polyps darkadapted and at $26.5{ }^{\circ} \mathrm{C}$ ) and light-adapted polyps after $285 \mathrm{~min}$ of maintenance in different temperatures: 29.0 ${ }^{\circ} \mathrm{C}(p<0.029), 31.0{ }^{\circ} \mathrm{C}(p<0.015)$, and $33.0{ }^{\circ} \mathrm{C}(p<0.008)$. Repeated measures ANOVA with $\mathrm{E}_{\mathrm{k}}$ showed that most variables tested (time, temperature, polyps, irradiance (dark/ light), time+temperature, and time+irradiance) showed highly significant differences $(p<0.001$; Table 1$)$. 


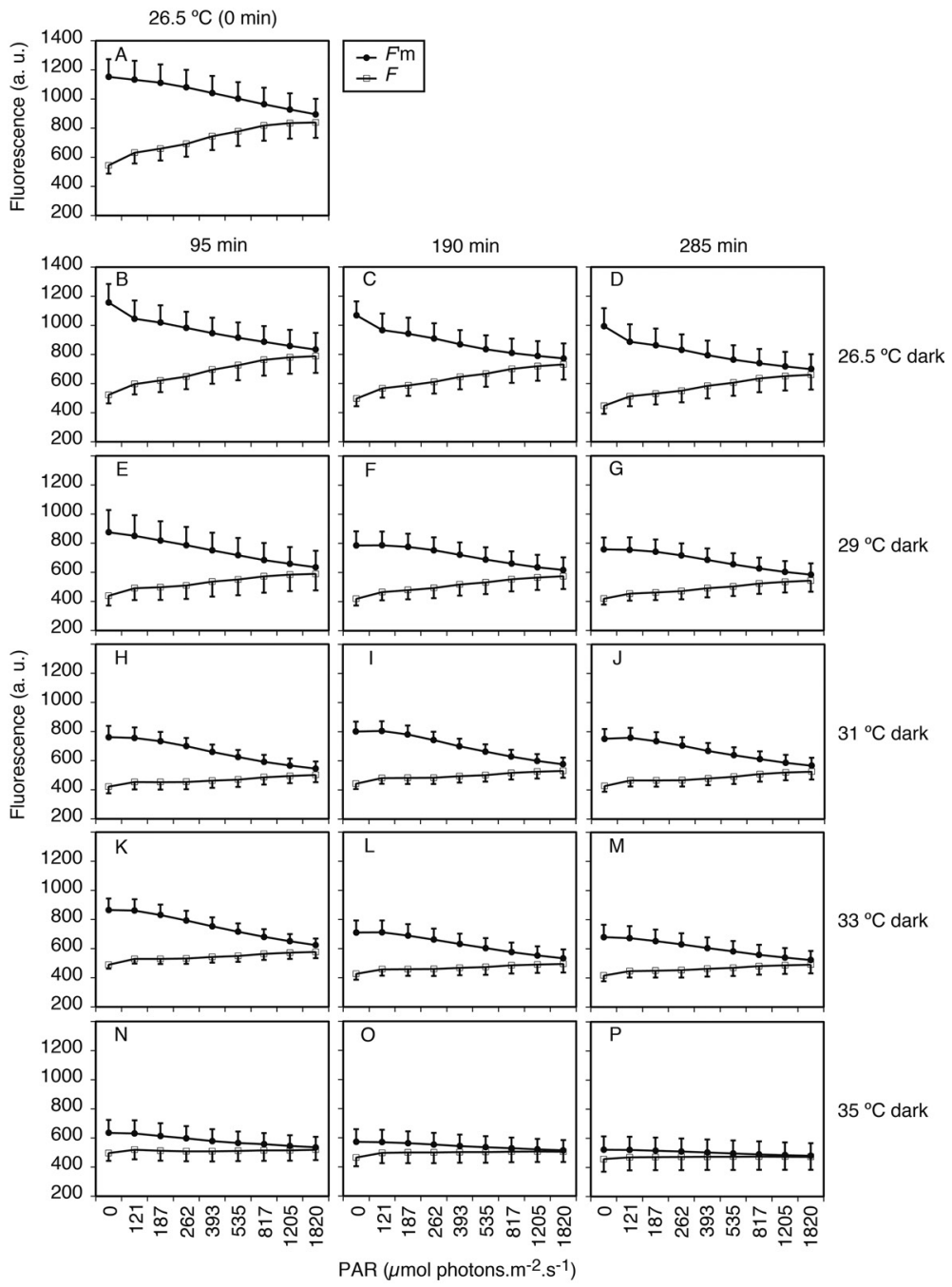

Figure 5. Stationary $(F)$ and maximum $\left(F_{\mathrm{m}}{ }^{\circ}\right)$ fluorescence of Mussismilia harttii polyps kept in the dark at different temperatures and experimental periods: $26.5^{\circ} \mathrm{C}(\mathrm{B}-\mathrm{D}), 29.0^{\circ} \mathrm{C}(\mathrm{E}-\mathrm{G}), 31.0^{\circ} \mathrm{C}(\mathrm{H}-\mathrm{J}), 33.0^{\circ} \mathrm{C}(\mathrm{K}-\mathrm{M})$, and $35.0{ }^{\circ} \mathrm{C}(\mathrm{N}-\mathrm{P}) ; 95 \mathrm{~min}(\mathrm{~B}, \mathrm{E}, \mathrm{H}, \mathrm{K}$, and $\mathrm{N}), 190 \mathrm{~min}(\mathrm{C}, \mathrm{F}, \mathrm{I}, \mathrm{L}$, and O), and $285 \min (\mathrm{D}, \mathrm{G}, \mathrm{J}, \mathrm{M}$, and $\mathrm{P})$. Bars show standard errors; $\mathrm{n}=6$.

EFFeCtive QuANTUM Yield of PSII $\left(\Phi_{\text {PSII }}\right.$ OR $\left.\Delta F / F^{\prime}{ }^{\prime}\right)$ AND NON-PHOTOCHEMICAL QUENCHING (NPQ)

As expected, there was an inverse relationship between $\Phi_{\mathrm{PSII}}$ and NPQ. The former decreased with higher irradiances, while the latter increased. At the beginning of the experiment (all polyps dark-adapted and at $26.5^{\circ} \mathrm{C}$ ), $\Phi_{\text {PSII }}$ started at circa 0.5 at the first pulse of saturating light. Subsequently this value progressively decreased at higher light intensities. NPQ values increased from zero at the first pulse to almost 0.3 at the last pulse of the RLC (Figures 7 and 8).

Dark-adapted polyps incubated at temperatures between $26.5^{\circ} \mathrm{C}$ and $33.0^{\circ} \mathrm{C}$ showed initial $\Phi_{\text {PSII }}$ values slowly decreasing to 0.4 as temperatures increased (Figure 7). Dark-adapted polyps incubated at $35.0{ }^{\circ} \mathrm{C}$ showed a strong decrease of the initial $\Phi_{\mathrm{PSII}}$ value after $95 \mathrm{~min}$ (58\% less than control dark-adapted polyps).

Comparatively, control light-adapted polyps (26.5 ${ }^{\circ} \mathrm{C}$ ) showed smaller $\Phi_{\text {PSII }}$ values than dark-adapted polyps (Figure 7 x Fig. 8). Even so, light-adapted polyps showed a stronger progressive decrease of the initial value of $\Phi_{\mathrm{PSII}}$ as temperatures increased (Figure 8). Decrease of the initial $\Phi_{\text {PSII }}$ values in light-adapted polyps incubated at $35.0{ }^{\circ} \mathrm{C}$ reached values $75 \%$ less than control light-adapted polyps after $95 \mathrm{~min}$.

At control temperatures $\left(26.5^{\circ} \mathrm{C}\right), \mathrm{NPQ}$ progress along the experiment was slightly smaller in dark-adapted (Figure 


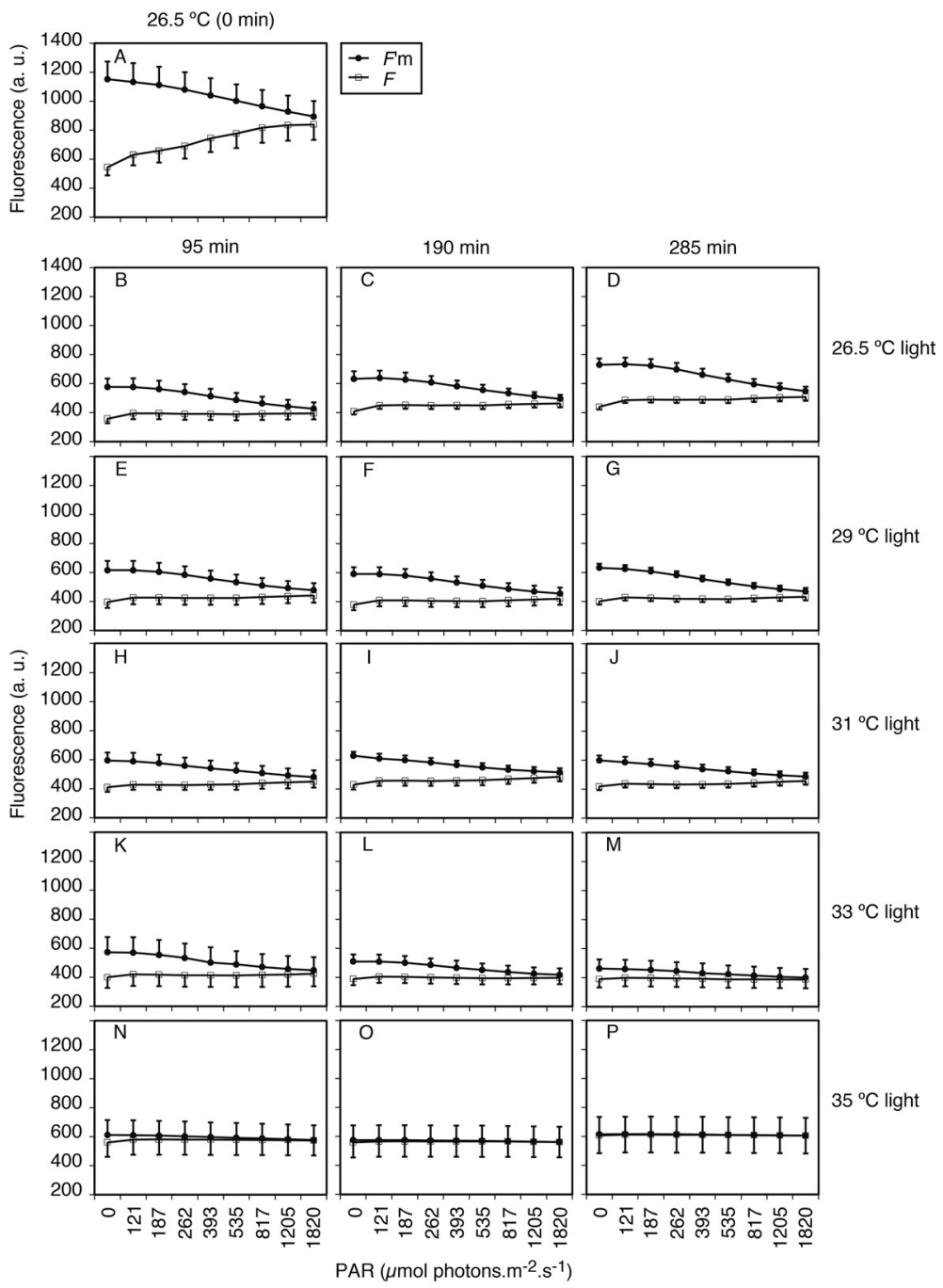

Figure 6. Stationary $(F)$ and maximum $\left(F^{\prime}{ }^{\prime}\right)$ fluorescence of Mussismilia harttii polyps exposed to light $\left(300 \mathrm{mmol}^{\mathrm{photons}} \mathrm{m}^{-2} . \mathrm{s}^{-1}\right)$ at different temperatures and experimental periods: $26.5^{\circ} \mathrm{C}(\mathrm{B}-\mathrm{D}), 29.0^{\circ} \mathrm{C}(\mathrm{E}-\mathrm{G}), 31.0^{\circ} \mathrm{C}(\mathrm{H}-\mathrm{J}), 33.0^{\circ} \mathrm{C}(\mathrm{K}-\mathrm{M})$, and $35.0^{\circ} \mathrm{C}(\mathrm{N}-\mathrm{P}) ; 95 \mathrm{~min}(\mathrm{~B}, \mathrm{E}, \mathrm{H}, \mathrm{K}$, and $\mathrm{N})$, $190 \min (\mathrm{C}, \mathrm{F}, \mathrm{I}, \mathrm{L}$, and $\mathrm{O})$, and $285 \mathrm{~min}(\mathrm{D}, \mathrm{G}, \mathrm{J}, \mathrm{M}$, and P). Bars show standard errors; $\mathrm{n}=6$.

7) than in light-adapted polyps (Figure 8). At $29.0^{\circ} \mathrm{C}$, NPQ of dark- and light-adapted polyps evolved with quite similar values. Dark-adapted polyps showed an increase in NPQ values at $31.0^{\circ} \mathrm{C}$, followed by a slight and heavy decrease at $33.0^{\circ} \mathrm{C}$ and $35.0^{\circ} \mathrm{C}$, respectively (Figure 7). In light-adapted polyps, there was a diverse tendency; NPQ values dropped almost continuously as temperatures were elevated, reaching near zero values at $35.0^{\circ} \mathrm{C}$ (Figure 8).

\section{Post-Experiment ReCOVERY}

Twenty-four hours after returning to normal conditions (aquarium at $\left.26.5^{\circ} \mathrm{C}\right), F_{\mathrm{v}} / F_{\mathrm{m}}$ showed that all polyps incubated at 26.5 (control) and $29.0^{\circ} \mathrm{C}$ fully recovered, with values close to the average for all polyps before the experiment
(0.659). At higher temperatures, there was an increasing tendency towards non-recovery. At $31.0^{\circ} \mathrm{C}$, one (out of six) dark-adapted and two (out of six) light-adapted polyps presented $F_{\mathrm{v}} / F_{\mathrm{m}}<0.390$. At $33.0^{\circ} \mathrm{C}$, only two (out of 12 and both dark-adapted) presented $F_{\mathrm{v}} / F_{\mathrm{m}}>0.600$, suggesting a full recovery. All polyps incubated at $35.0^{\circ} \mathrm{C}$ died.

Bifactorial ANOVA (light and temperature) showed differences only among temperatures $(F=70.5104, d f=4$, $p<0.001$ ). Tukey's (HSD) post-Hoc test showed significant differences between the highest $\left(33.0\right.$ and $\left.35.0{ }^{\circ} \mathrm{C}\right)$ and lowest temperatures $\left(26.5,29.0\right.$, and $\left.31.0^{\circ} \mathrm{C}\right)(p<0.001)$. All data were normal (Kolmogorov-Smirnov, $p>0.20$ ). Levene's test indicated heterocedastic variances $\left(\mathrm{F}_{4,60}=\right.$ 15.300: $p<0.001)$. 

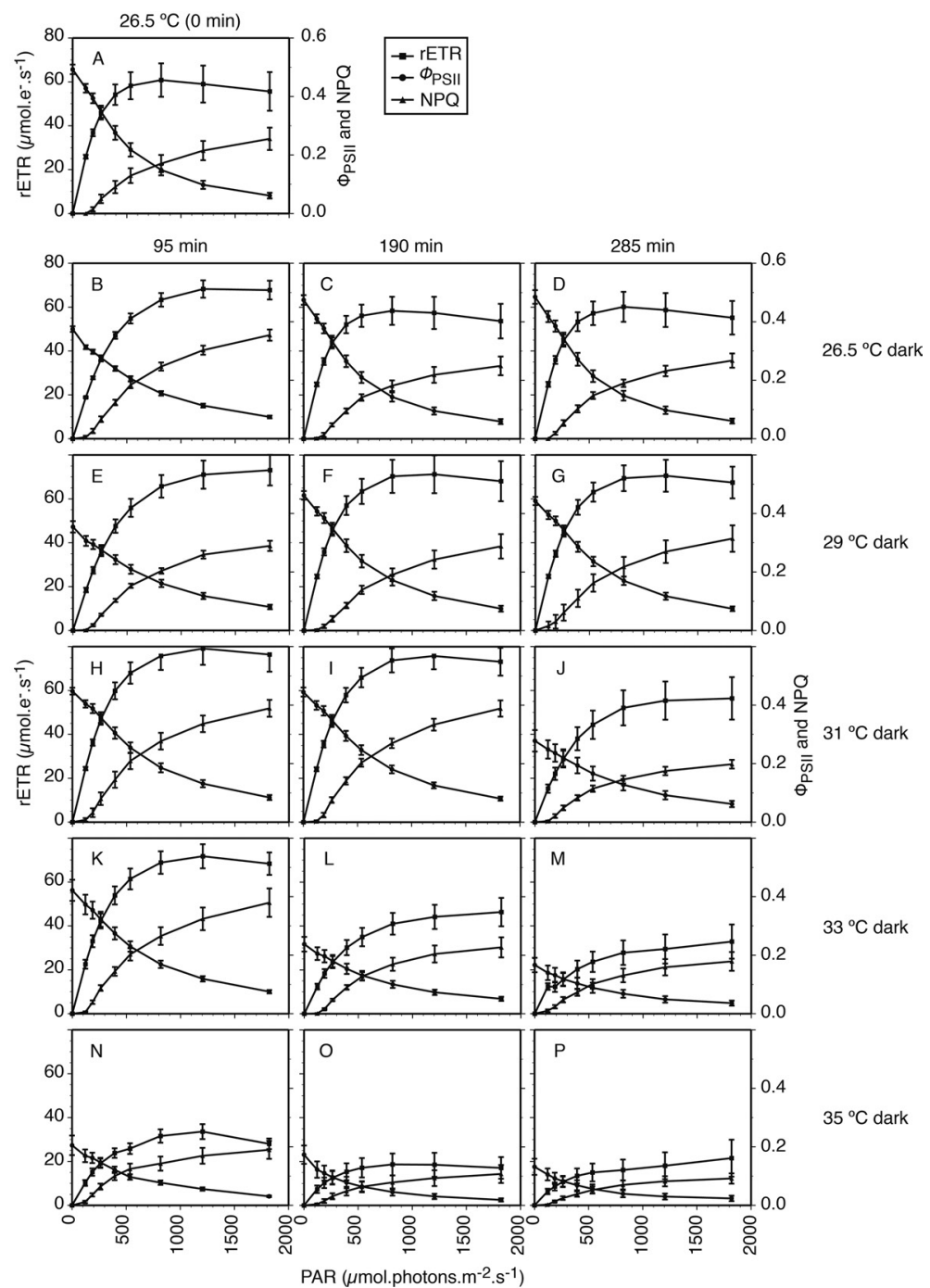

$35^{\circ} \mathrm{C}$ dark

Figure 7. Rapid light curves with relative electron transport rate (rETR), effective quantum yield of PSII ( $\Phi_{\text {PSII }}$ ), and non-photochemical quenching (NPQ) of dark-adapted Mussismilia harttii polyps exposed to different temperatures and experimental periods: $26.5^{\circ} \mathrm{C}(\mathrm{B}-\mathrm{D}), 29.0^{\circ} \mathrm{C}(\mathrm{E}-\mathrm{G}), 31.0$ ${ }^{\circ} \mathrm{C}(\mathrm{H}-\mathrm{J}), 33.0^{\circ} \mathrm{C}(\mathrm{K}-\mathrm{M})$, and $35.0{ }^{\circ} \mathrm{C}(\mathrm{N}-\mathrm{P})$; $95 \mathrm{~min}(\mathrm{~B}, \mathrm{E}, \mathrm{H}, \mathrm{K}$, and N), $190 \mathrm{~min}(\mathrm{C}, \mathrm{F}, \mathrm{I}, \mathrm{L}$, and O), and $285 \mathrm{~min}(\mathrm{D}, \mathrm{G}, \mathrm{J}, \mathrm{M}$, and P). Bars show standard error; $\mathrm{n}=6$.

\section{DISCUSSION}

This study has explored how higher temperatures combined with light will impact a coral-dinoflagellate symbiosis in Mussismilia harttii in Porto Seguro, State of Bahia, Brazil. No visible bleaching of coral samples was seen during nearly $5 \mathrm{~h}$ of maintenance at temperatures between 26.5 and $35.0^{\circ} \mathrm{C}$, either in the dark or in the light. Such a result is compatible with those of other studies. Bleaching was reported in dark-adapted Stylophora pistillata only $24 \mathrm{~h}$ after exposure to excess irradiance $(2000 \mu \mathrm{mol}$ photons.m$\left.{ }^{2} \cdot \mathrm{s}^{-1}\right)$ at temperatures between 21.0 and $26.5{ }^{\circ} \mathrm{C}$ (JONES; HOEGH-GULDBERG, 2001). JONES et al. (1998) did not see bleaching in $S$. pistillata after $4 \mathrm{~h}$ at temperatures up to $34.0^{\circ} \mathrm{C}$. However, they observed a significant loss (cell count) of endosymbionts under natural light (but not under artificial light). Solar radiation is an environmental factor that significantly affects the intensity of bleaching in heat-stressed corals (LESSER; FARRELL, 2004). However, most of the change in photosynthetic activity of Mussismilia harttii endosymbionts occurred in the first 95 min of the experiment. Subsequent times showed stability $\left(31.0^{\circ} \mathrm{C}\right.$ or less) or a continuing drop $\left(33.0^{\circ} \mathrm{C}\right.$ and 35.0 ${ }^{\circ} \mathrm{C}$ ) in photosynthetic activity. PUTNAM and EDMUNDS (2011) demonstrated that temperature fluctuations going beyond the limits of high or low temperatures could 

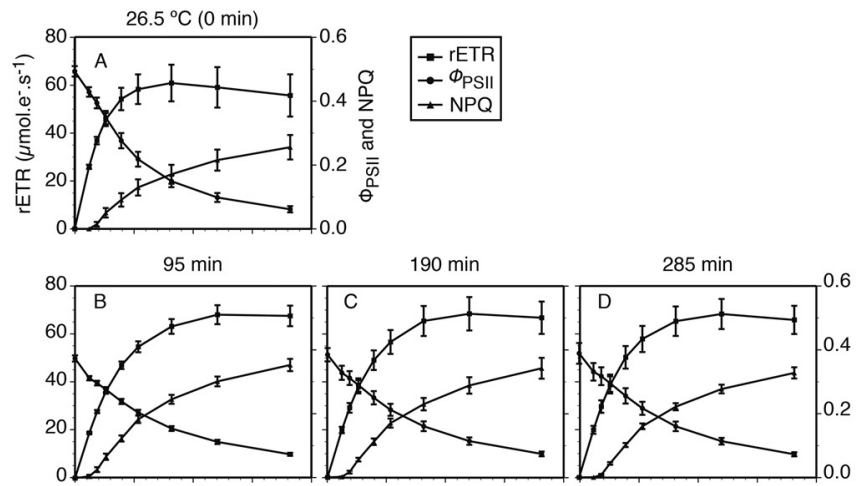

$26.5^{\circ} \mathrm{C}$ light
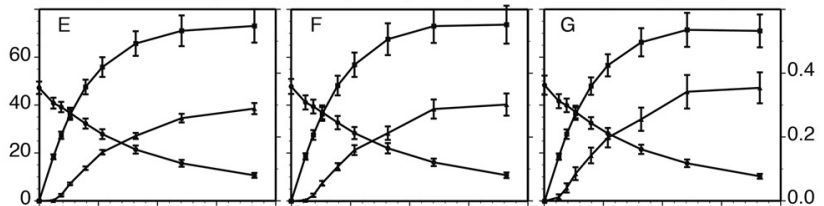

$29^{\circ} \mathrm{C}$ light
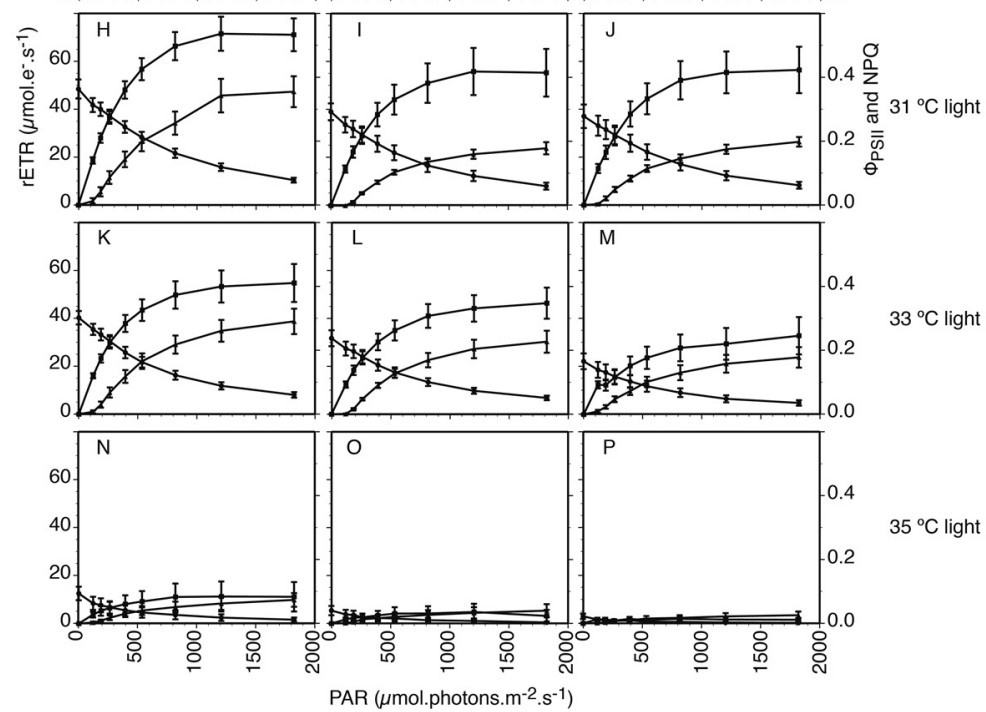

Figure 8. Rapid light curves with relative electron transport rate (rETR), effective quantum yield of PSII ( $\Phi_{\text {PSII }}$ ), and non-photochemical quenching (NPQ) of light-adapted Mussismilia harttii polyps exposed to different temperatures and experimental periods: $26.5^{\circ} \mathrm{C}(\mathrm{B}-\mathrm{D}), 29.0^{\circ} \mathrm{C}(\mathrm{E}-\mathrm{G}), 31.0$ ${ }^{\circ} \mathrm{C}(\mathrm{H}-\mathrm{J}), 33.0^{\circ} \mathrm{C}(\mathrm{K}-\mathrm{M})$, and $35.0{ }^{\circ} \mathrm{C}(\mathrm{N}-\mathrm{P}) ; 95 \mathrm{~min}(\mathrm{~B}, \mathrm{E}, \mathrm{H}, \mathrm{K}$, and N), $190 \mathrm{~min}(\mathrm{C}, \mathrm{F}, \mathrm{I}, \mathrm{L}$, and O), and $285 \mathrm{~min}(\mathrm{D}, \mathrm{G}, \mathrm{J}, \mathrm{M}$, and P). Bars show standard error; $\mathrm{n}=6$.

cause potentially harmful responses equivalent to that occurring in corals exposed to constant high temperatures. Their experiments showed significantly different results depending on the time period over which they were carried out: especially were the density of Symbiodinium and $F_{\mathrm{v}}$ $F_{\mathrm{m}}$ responses significantly different only in their Trial 1 - when natural seasonal Symbiodinium densities were higher (PUTNAM; EDMUNDS, 2011). Corals growing in environments with large daily temperature variability (up to $7.0^{\circ} \mathrm{C}$ ) and temperature extremes of up to $37.0^{\circ} \mathrm{C}$ were highly susceptible to coral bleaching when exposed to heat stress (SCHOEPF et al., 2015). Corals were highly sensitive to daily average temperatures exceeding their maximum monthly mean by $1{ }^{\circ} \mathrm{C}$ for only a few days (SCHOEPF et al., 2015).

High sea surface temperature combined with high levels of solar irradiance has been found to be responsible for the induction of oxidative stress that triggers disruption of the symbiosis between cnidarians and Symbiodinium (ROBERTY et al., 2015). There was a gradual reduction of $F_{\mathrm{v}} / F_{\mathrm{m}}$ as temperature increased, with a further drop in the presence of light, indicating a synergistic effect of these factors - as seen in other studies (FITT; WARNER, 1995; DUNNE; BROWN, 1996, 2001; GLYNN, 1996; WARNER et al., 1996; JONES et al., 1998; HOEGH-GULDBERG, 1999; FITT et al., 2001; LESSER; FARRELL, 2004). 
Similar physiological responses were also observed at low temperatures for Montipora digitata (SAXBY et al., 2003) under high intensity light, clearly demonstrating the exacerbated effect caused by light. In the present study, especially at high temperatures $\left(33.0^{\circ} \mathrm{C}\right.$ and $\left.35.0^{\circ} \mathrm{C}\right)$, light aggravated the effect of temperature, resulting in a rapid reduction in $F_{\mathrm{v}} / F_{\mathrm{m}}, \Phi_{\mathrm{PSI}}, \mathrm{rETR}_{\max }$, and $\alpha$.

$F_{\mathrm{v}} / F_{\mathrm{m}}$ significantly decreased only when the coral Pocillopora damicornis was incubated at high temperatures $\left(32.0{ }^{\circ} \mathrm{C}\right)$ and high irradiance $\left(475 \mathrm{mmol}\right.$ photons. $\left.\mathrm{m}^{2} \cdot \mathrm{s}^{-1}\right)$, while at the same temperature and $225 \mathrm{mmol}$ photons.m${ }^{2} \cdot \mathrm{s}^{-1}$ PSII activity was not significantly reduced (HILL et al., 2005). High irradiances alone diminished $F_{\mathrm{v}} / F_{\mathrm{m}}$ values in endosymbionts of the corals Stylophora pistillata (JONES; HOEGH-GULDBERG， 2001). Response appears to be species-specific because other studies have shown that temperature alone could decrease $F_{\mathrm{v}} / F_{\mathrm{m}}$ (WARNER et al., 1996), even at subsaturating irradiances (40 $\mu$ mol photons. $\mathrm{m}^{-2} \cdot \mathrm{s}^{-1}$ ) (IGLESIAS-PRIETO, 1995).

Chlorophyll fluorescence emission under ambient temperature is almost entirely related to the PSII and the ratio $F_{\mathrm{v}} / F_{\mathrm{m}}$, which describes the maximum quantum yield of the PSII (BJÖRKMAN; DEMMIG, 1987), has been widely used as diagnostic of environmental stresses on the physiology of photosynthetic organisms (SCHREIBER et al., 1994; CAMPBELL et al., 1998). Therefore, the ratio $F_{\mathrm{v}} / F_{\mathrm{m}}$ adequately reflects the influence of temperature and light on the photosynthetic activity of the endosymbionts of $M$. harttii. As mentioned, there is a decline of photosynthetic activity when the rate of absorption of light energy exceeds its utilization, i. e., photoinhibition (OSMOND, 1994). Photosynthetic organisms developed a fast and efficient process to repair photodamage to the PSII (Aro et al., 1993; 2005; TAKAHASHI; MURATA, 2008). Therefore, the extent of photoinhibition depends on the balance between photodamage to the PSII and the repair process. Elevated temperatures do not accelerate the damage to the PSII, but can inhibit its repair (MURATA et al., 2007; TAKAHASHI; MURATA, 2008; TAKAHASHI et al., 2009). These authors showed that the sensitivity to photobleaching in Symbiodinium under thermal stresses differs between Clade A Symbiodinium strains. The repair process was strongly inhibited by temperatures exceeding $31.0^{\circ} \mathrm{C}$ in one strain but only weakly in other. Therefore, we suggest that the photodamage to $M$. harttii endosymbionts triggered by temperatures of $33.0{ }^{\circ} \mathrm{C}$ and $35.0{ }^{\circ} \mathrm{C}$ results from a decline of the repair process, as well as the effect of light on the PSII. This would explain the enhanced effect when polyps were incubated under both factors: high temperatures and light. Temperature alone also caused an effect on the PSII, as there was a severe decline of $F_{\mathrm{v}} / F_{\mathrm{m}}$ under $35.0^{\circ} \mathrm{C}$ even in the absence of light.

Rapid light curves (RLCs) at the beginning of the experiments (dark-adapted polyps kept at $26.5{ }^{\circ} \mathrm{C}$ for all treatments) showed a gradual increase of the stationary fluorescence (circa 54\%), indicating a gradual closing of the reaction centers, which impair their photochemical processes (RALPH; GADEMANN, 2005). Concomitantly, there was a decrease of the maximum fluorescence of light-adapted samples, suggesting the onset of nonphotochemical quenching mechanisms (NPQ). These mechanisms became predominant under irradiances higher than the minimum saturating irradiances $\left(\mathrm{E}_{\mathrm{k}}\right)$. In fact, there was a gradual increase in NPQ, especially at irradiances over $300 \mathrm{mmol}$ photons. $\mathrm{m}^{-2} \cdot \mathrm{s}^{-1}$, which correspond to $E_{k}$ under the initial conditions of the experiment. The relative electron transport rate (rETR) showed a slight decline at the end of the RLCs, probably associated with an increase in energy dissipation as heat (down-regulation of the PSII) as there was not enough time of light exposure to damage the photosystems (RALPH; GADEMANN, 2005). The effect of temperature on the maximum relative electron transport rates $\left(\mathrm{rETR}_{\max }\right)$ seems to result from a balance between a protection and an inhibition of the photosynthetic activity (OSMOND, 1994). Light-adapted polyps showed dynamic photoinhibition (photoprotection) at temperatures between $26.5^{\circ} \mathrm{C}$ and $31.0^{\circ} \mathrm{C}$, as suggested by the decline in $\alpha$, the rise in $\mathrm{E}_{\mathrm{k}}$, and the continuation of $\mathrm{rETR}_{\max }$. The gradual declines of $\alpha$ and $\mathrm{rETR}_{\max }$ in samples incubated at $33.0{ }^{\circ} \mathrm{C}$ suggest that the onset of chronic photoinhibition (photodamage) occurs in lightadapted polyps at temperatures above $31.0^{\circ} \mathrm{C}$. ROBERTY et al. (2015) demonstrated for the first time that combined heat and light stress inactivate antioxidant capacities of the water-water cycle, WWC. In corals under high light and at $33.0{ }^{\circ} \mathrm{C}, \mathrm{O}_{2}$-dependent electron transport had significantly increased relative to total electron transport. This increase was concomitant with a twofold increase in ROS generation compared with the treatment at $26.0^{\circ} \mathrm{C}$, while enzymes involved in the WWC were largely inactivated. Photosynthetic organisms developed mechanisms to dissipate excessive light-energy as heat (non-photochemical quenching - NPQ), which can be quantified through the decline of the fluorescence of the chlorophyll (WARNER; BERRY-LOWE, 2006). Among protection mechanisms, the xanthophyll cycle stands out 
in Symbiodinium sp. and other microalgae (LAVAUD et al., 2004) and can be inferred by the NPQ (BROWN et al., 1999; SCHREIBER, 2004). NPQ plays an important role during bleaching (HILL et al., 2004a; HILL et al., 2005). Therefore, the fast development of NPQ in endosymbionts found in $M$. harttii is probably due to the xanthophyll cycle acting to protect against factors as temperature and irradiance. Recovery studies showed different results. Ten hours after removal of stress conditions, at high temperatures, were enough for PSII recovery in Acropora nobilis (HILL et al., 2004b). Acropora digitifera incubated at $28.0{ }^{\circ} \mathrm{C}$ showed complete recovery only $3 \mathrm{~h}$ after decreasing light from 500 to $20 \mathrm{mmol}$ photons. $\mathrm{m}^{2} \mathrm{~s}^{1}$. A similar experiment with $A$. digitifera incubated at $32.0^{\circ} \mathrm{C}$ resulted in $F_{\mathrm{v}} / F_{\mathrm{m}}$ significantly smaller than original values even $7 \mathrm{~h}$ after decreasing light intensity (TAKAHASHI et al., 2004). Despite the considerable bleaching observed at low temperatures, there was no recovery of $F_{\mathrm{v}} / F_{\mathrm{m}}$ for $M$. digitata exposed to $12.0^{\circ} \mathrm{C}$ for more than $12 \mathrm{~h}$ (SAXBY et al., 2003).

While bleaching was not observed in $M$. harttii, this coral showed incomplete recovery (estimated $24 \mathrm{~h}$ after ceasing the stress) of three out of 12 polyps incubated at $31.0^{\circ} \mathrm{C}$, with light-adapted polyps showing a slightly inferior recovery. The full recovery of only two (out of 12) polyps incubated at $33.0{ }^{\circ} \mathrm{C}$ may be due to the dominance of different thermal tolerant zooxanthellae clades. Clades $\mathrm{A}, \mathrm{B}$, and $\mathrm{C}$ have been recorded on the Southeastern Brazilian coast (BAKER, 2003), but only clade $\mathrm{C}$ on the Northeastern coast (closer to the Equator), including areas to the North and to the South of our specimens (BAKER, 2003; COSTA et al., 2008). However, this hypothesis needs to be tested. Positive thermal anomalies of up to $0.75{ }^{\circ} \mathrm{C}$ were recorded during the summer, between 1998 and 2005, in Bahia State (including the Porto Seguro area), resulting in different degrees of mild to severe bleaching (LEÃO et al., 2008). The presence of thermal-tolerant endosymbionts may be fostered by such anomalies (see BAKER et al., 2004).

Although light enhanced the harmful effects of increased temperatures, there was a complete recovery of all polyps maintained at $26.5^{\circ} \mathrm{C}$ and $29.0^{\circ} \mathrm{C}$, despite the presence of light. Recovery data for polyps kept at $31.0^{\circ} \mathrm{C}$ showed that this temperature (depending on time of exposure) seems to mark the threshold before more serious damage occurs. There are no species or genotypes of corals capable of surviving a water temperature rise between $3.0{ }^{\circ} \mathrm{C}$ and $6.0{ }^{\circ} \mathrm{C}$ for more than a month
(HOEGH-GULDBERG, 2009), or reef builders that have the ability to tolerate projected changes in sea temperature (see several general circulation models in HOEGHGULDBERG, 1999), as predicted for the end of this century (IPCC, 2007). Therefore, unless the presence of thermotolerant endosymbionts is confirmed and corals are able to establish a population with such clades, continued exposure to temperatures higher than $31.0^{\circ} \mathrm{C}$ can lead to mass bleaching of $M$. harttii in the Porto Seguro area.

Coral reefs have experienced several large-scale bleaching events due to climate change and these events are expected to increase in frequency and severity in the future jeopardizing the survival of coral reefs. The geographically large-scale bleaching observed in the South Atlantic in 2010 reported only minor bleaching events. In Porto Seguro (locality of our experiments), seawater temperatures reached $31.0^{\circ} \mathrm{C}$ during several days in late summer/early autumn (PROJETO CORAL VIVO, unp. data). Under these conditions, our experiments showed a few affected colonies, suggesting that our experimental conditions are correctly reflecting responses observed in the field in this area.

\section{ACKNOWLEDGEMENTS}

We wish to thank Nuno Seabra, Leones Lopes for their laboratory assistance; Renata Arantes, Antonio Santos and Sandro Santana for field assistance; Paulo Paiva and Carla Zilberberg for help with statistical analyses. Funding was provided in part by Projeto Coral Vivo, sponsored by Petrobras Socioenvironmental Program and Arraial d'Ajuda Eco Parque. APMW is grateful for a graduate fellowship from CENPES/Petrobras, and CBC for a research fellowship from the Brazilian Research Council (CNPq).

\section{REFERENCES}

ARO, E. M.; VIRGIN, I.; ANDERSON, B. Photoinhibition of photosystem II. Inactivation, protein damage and turnover. Biochim. Biophys. Acta, v. 1143, n. 2, p. 113-134, 1993.

ARO, E. M.; SUORSA, M.; ROKKA, A.; ALLAHVERDIYEVA, Y.; PAAKKARINEN, V.; SALEEM, A.; BATTCHIKOVA, N.; RINTAMÄKI, E. Dynamics of photosystem II: a proteomic approach to thylakoid protein complexes. J. Exp. Bot., v. 56, n. 411, p. 347-356, 2005.

BAKER, A.C., STARGER, C.J., MCCLANAHAN, T.R., GLYNN, P.W., 2004. Corals' adaptive response to climate change. Nature 430, 741.

BAKER, A. C. Flexibility and Specificity in Coral-Algal Symbiosis: diversity, ecology, and biogeography of Symbiodinium. Ann. Rev. Ecol. Evol. Syst., v. 34, p. 661-689, 2003. 
BJÖRKMAN, O.; DEMMIG, B. Photon yield of O2 evolution and chlorophyll fluorescence characteristics at $77 \mathrm{~K}$ among vascular plants of diverse origens. Planta, v. 170, n. 4, p. 789504, 1987.

BROWN, B. E.; AMBARSARI, I.; WARNER, M. E.; FITT, W. K.; DUNNE, R. P.; GIBB, S. W.; CUMMINGS, D. G. Diurnal changes in photochemical efficiency and xanthophylls concentrations in shallow water reef corals: evidence for photoinhibition and photoreception. Coral Reefs, v. 18, p. 99105, 1999.

BUDDEMEIER, R. W.; KLEYPAS, J. A.; ARONSON, R. B. Coral Reefs and Global Climate Change. Potential contributions of climate change to stresses on coral reef ecosystems. Arlington: Pew Center on Global Climate Change, 2004.

CAMPBELL, D.; HURRY, V.; CLARKE, A. K.; GUSTAFSSON, P.; OQUIST, G. Chlorophyll fluorescence analysis of cyanobacterial photosynthesis and acclimation. Microbiol. Mol. Biol. Rev., v. 62, n. 3, p. 667-683, 1998.

CASTRO, C. B.; PIRES, D. O. A bleaching event on a Brazilian coral reef. Rev. Bras. Oceanogr., v. 47, n. 1, p. 87-90, 1999.

CASTRO, C. B.; PIRES, D. O. Brazilian coral reefs: what we already know and what is still missing. Bull. Mar. Sci., v. 69, n. 2, p. 357-371, 2001.

COSTA, C. F.; SASSI, R.; GORLACH-LIRA, K. Zooxanthellae genotypes in the Siderastrea stellata from coastal reefs in northeastern Brazil. J. Exp. Mar. Biol. Ecol., v. 367, n. 2, p. 149-152, 2008.

DUNNE, R. P.; BROWN, B. E. Penetration of solar UVB radiation in shallow tropical waters and its potential biological effects on coral reefs; results from the central Indian Ocean and Andaman Sea. Mar. Ecol. Prog. Ser., v. 144, p. 109-118, 1996.

DUNNE, R. P.; BROWN, B. E. The influence of solar radiation on bleaching of shallow water reef corals in the Andaman Sea, 1993-1994. Coral Reefs, 20:201-210 [doi: 10.1007/ s003380100160], 2001

BRASIL. Ministério do Meio Ambiente, Secretaria de Biodiversidade e Florestas. In: FERREIRA, B. P.; MAIDA, M. (ed.). Monitoramento dos recifes de coral do Brasil situação atual e perspectivas. Brasília: Ministério do Meio Ambiente, 2006.

FITT, W. K.; BROWN, B. E.; WARNER, M. E.; DUNNE, R. P. Coral bleaching: interpretation of thermal tolerance limits and thermal thresholds in tropical corals. Coral Reefs, v. 20, n. 1, p. $51-65,2001$.

FITT, W. K.; WARNER, M. E. Bleaching patterns of four species of Caribbean reef corals. Biol. Bull., v. 189, n. 3, p. 298-307, 1995.

FRISCH, A. J.; ULSTRUP, K. E.; HOBBS, J. A. The effects of clove oil on coral: An experimental evaluation using Pocillopora damicornis (Linnaeus). J. Exp. Mar. Biol. Ecol., v. 345, n. 2, p. 101-109, 2007.

GENTY, B.; BRIANTAIS, J. M.; BAKER, N. R. The relation between the quantum yield of photosynthetic electron transport and quenching of chlorophyll fluorescence. Biochim. Biophys. Acta, v. 990, n. 1, p. 87-92, 1989.

GLYNN, P. W. Coral reef bleaching: facts, hypotheses and implications. Glob. Change Biol., v. 2, n. 6, p. 495-509, 1996.
HILL, R.; SCHREIBER, U.; GADEMANN, R.; LARKUM, A. W. D.; KÜHL, M.; RALPH, P. J. Spatial heterogeneity of photosynthesis and the effect of temperature-induced bleaching conditions in three species of corals. Mar. Biol., v. 144, n. 4, p. 633-640, 2004a.

HILL, R.; LARKUM, A. W. D.; FRANKART, C.; KÜHL, M.; RALPH, P. J. Loss of functional Photosystem II reaction centres in zooxanthellae of corals exposed to bleaching conditions: using fluorescence rise kinetics. Photosynth. Res., v. 82 , n. 1 , p. $59-72,2004$ b.

HILL, R.; FRANKART, C.; RALPH, P. J. Impact of bleaching conditions on the component of non-photochemical quenching in the zooxanthellae of a coral. J. Exp. Mar. Biol. Ecol., v. 322, n. 1, p. 83-92, 2005.

HOEGH-GULDBERG, O. Climate change, coral bleaching and the future of the world's coral reefs. Mar. Freshw. Res., v. 50, n. 8, p. 839-866, 1999.

HOEGH-GULDBERG, O. Climate change and coral reefs: Trojan horse or false prophecy? Coral Reefs, v. 28, n. 3, p. 569-575, 2009.

IGLESIAS-PRIETO, R. The effects of elevated temperature on the photosynthetic responses of symbiotic dinoflagellates. In: MATHIS, P. (Ed.). Light to Biosphere. Dordrecht: Kluwer, 1995. p. 793-796.

INTERGOVERNMENTAL PANEL ON CLIMATE CHANGES (IPCC). Climate Change 2007: Synthesis Report. In: Core Writing Team, PACHAURI, R. K.; A. REISINGER, A. (Eds.). Contribution of Working Groups I, II and III to the Fourth Assessment Report of the Intergovernmental Panel on Climate Change. Geneva: IPCC, 2007. 104 p.

JONES, R. J.; HOEGH-GULDBERG, O.; LARKUN, A. W. D.; SCHREIBER, U. Temperature-induced bleaching of corals begins with impairment of the $\mathrm{CO}_{2}$ fixation mechanism in zooxanthellae. Plant Cell Environ., v. 21, n. 12, p. 1219-1230, 1998.

JONES, R. J.; WARD, S.; AMRI, A. Y.; HOEGH-GULDBERG, $O$. Changes in quantum efficiency of Photosystem II of symbiotic dinoflagellates of corals after heat stress, and of bleached corals sampled after the 1998 Great Barrier Reef mass bleaching event. Mar. Freshw. Res., v. 51, n. 1, p. 6371,2000

JONES, R. J.; HOEGH-GULDBERG, O. Diurnal changes in the photochemical efficiency of the symbiotic dinoflagellates (Dinophyceae) of corals: photoprotection, photoinactivation and the relationship to coral bleaching. Plant Cell Environ., v. 24, n. 1, p. 89-99, 2001.

KUGURU, B.; ACHITUV, Y.; GRUBER, D. F.; TCHERNOV, D. Photoacclimation mechanisms of corallimorpharians on coral reefs: Photosynthetic parameters of zooxanthellae and host cellular responses to variation in irradiance. J. Exp. Mar. Biol. Ecol., v. 394, n. 1-2, p. 53-62, 2010.

LAVAUD, J.; ROUSSEAU, B.; ETIENNE, A. L. General features of photoprotection by energy dissipation in planktonic diatoms (Bacillariophyceae). J. Phycol., v. 40, n. 1, p. 130137, 2004.

LEÃO, Z. M. A. N.; DOMINGUEZ, J. M. L. Tropical coast of Brazil. Mar. Poll. Bull., v. 41, n. 1-6, p. 112-122, 2000.

LEÃO, Z. M. A. N.; KIKUCHI, R. K. P.; TESTA, V. Corals and Coral Reefs of Brazil. In: CORTÊS, J. (Ed.). Latin America Coral Reefs. Amsterdam: Elsevier Publisher, 2003. p. 9-52. 
LEÃO, Z. M. A. N.; KIKUCHI, R. K. P.; OLIVEIRA, M. D. M. Branqueamento de corais nos recifes da Bahia e sua relação com eventos de anomalias térmicas nas águas superficiais do oceano. Biota Neotrop., v. 8, n. 3, p. 69-82, 2008.

LESSER, M. P.; FARRELL, J. H. Exposure to solar radiation increases damage to both host tissue and algal symbionts of corals during thermal stress. Coral Reefs, v. 23, n. 3, p. 367337, 2004.

MIGOTTO, A. E. Anthozoan bleaching on the southeastern coast of Brazil in the summer of 1995. Proceedings of the International Conference on Coelenterate Biology. Leeuwenhorst; 1997. p. 329-335.

MUMBY, P. J.; CHISHOLM, J. R. M.; EDWARDS, A. J.; ANDREFOUET, S.; JAUBERT, J. Cloudy weather may have saved Society Island reef corals during the 1998 ENSO event. Mar. Ecol. Prog. Ser., v. 222, p. 209-216, 2001.

MURATA, N., TAKAHASHI, S., NISHIYAMA, Y., ALLAKHVERDIEV, S. I. (2007) Photoinhibition of photosystem II underenvironmental stress. Biochim. Biophys. Acta $1767,414-421$.

NUNES, F.; FUKAMI, H.; VOLLMER, S. V.; NORRIS, R. D.; KNOWLTON, N. Re-evaluation of the systematics of the endemic corals of Brazil by molecular data. Coral Reefs, v. 27, n. 2, p. 423-432, 2008.

OLIVER, J. K.; BERKELMANS, R.; EAKIN, C. M. Coral bleaching in space and time. In: VAN OPPEN, M. J. H.; LOUGH, J. M. (Eds.). Coral Bleaching. Patterns, processes, causes and consequences. Berlin: Springer-Verlag, 2009. p. 21-39.

OSMOND, C. B. What is photoinhibition: some insights from comparisons of sun and shade plants. In: BAKER, N. K.; BOWYER, J. R. (Eds.) Photoinhibition of photosynthesis: from molecular mechanisms to the field. Oxford: BIOS Scientific, 1994. p. 1-24.

PHILIPP, E.; FABRICIUS, K. Photophysiological stress in scleractinian corals in response to short-term sedimentation. J. Exp. Mar. Biol. Ecol., v. 287, n. 1, p. 57-58, 2003.

PUTNAM, H. M.; EDMUNDS, P. J. The physiological response of reef corals to diel fluctuations in seawater temperature. J. Exp. Mar. Biol. Ecol., v. 392, n. 2, p. 216-223, 2011.

RALPH, P. J.; GADEMANN, R.; LARKUM, A. W. D.; SCHREIBER, U. In situ underwater measurements of photosynthetic activity of coral zooxanthellae and other reefdwelling dinoflagellate endosymbionts. Mar. Ecol. Prog. Ser., v. 180 , p. $139-147,1999$.

RALPH, P. J.; GADEMANN, R. Rapid light curves: a powerful tool to assess photosynthetic activity. Aquat. Bot., v. 82, n. 3, p. 222-237, 2005.

ROBERTY, S.; FRANSOLET, D.; CARDOL, P.; PLUMIER, J. C.; FRANCK, F. Imbalance between oxygen photoreduction and antioxidant capacities in Symbiodinium cells exposed to combined heat and high light stress. Coral Reefs, v. 34, n. 4, p. 1063-1073, 2015.

ROGERS, C. S. Responses of coral reefs and reef organisms to sedimentation. Mar. Ecol. Prog. Ser., v. 62, p. 185-202, 1990.

SAXBY, T.; DENNISON, W. C.; HOEGH-GULDBERG, O. Photosynthetic responses of the coral Montipora digitata to cold temperature stress. Mar. Ecol. Prog. Ser., v. 248, p. 8597, 2003.
SCHOEPF, V.; STAT, M.; FALTER, J. L.; MCCULLOCH, M. T. Limits to the thermal tolerance of corals adapted to a highly fluctuating, naturally extreme temperature environment. Sci. Rep., v. 5, p. 17639, 2015.

SCHREIBER, U.; BILGER, W.; NEUBAUER, C. Chlorophyll fluorescence as a non-intrusive indicator for rapid assessment of in vivo photosynthesis. In: SCHULZE, E. D.; CALDWELL, M. M. (Eds.). Ecophysiology of Photosynthesis, 100. Berlim: Springer-Verlag, 1994. p. 49-79.

SCHREIBER, U. Pulse-amplitude (PAM) fluorometry and saturation pulse method: an overview. In: PAPAGEORGIOU, G. C.; GOVINDJEE. (Eds.). Chlorophyll fluorescence: a signature of photosynthesis. Advances in photosynthesis and respiration series. Dordrecht: Kluwer, 2004. p. 279-319.

SEIBECK, U. E.; MARSHALL, N. J.; KLÜTER, A.; HOEGHGULDBERG, O. Monitoring coral bleaching using a colour reference card. Coral Reefs, v. 25, n. 3, p. 453-460, 2006.

TAKAHASHI, S.; NAKAMURA, T.; SAKAMIZU, M.; VAN WOESIK, R.; YAMASAKI, H. Repair machinery of symbiotic photosynthesis as the primary target of heat stress for reef-building corals. Plant Cell Physiol., v. 45, n. 2, p. 251-255, 2004.

TAKAHASHI, S.; MURATA, N. How do environmental stress accelerate photoinhibition? Trends Plants Sci., v. 3, n. 4, p. 178-182, 2008.

TAKAHASHI, S.; WHITNEY, S. M.; BADGER, M. R. Different thermal sensitivity of the repair of photodamaged photosynthetic machinery in cultured Symbiodinium species. Proc. Natl. Acad. Sci. U. S. A., v. 106, n. 9, p. 3237-3242, 2009.

VAN OPPEN, M. J. H.; BAKER, A. C.; COFFROTH, M. A.; WILLIS, B. L. Bleaching resistance and the role of algal endosymbionts. In: VAN OPPEN, M. J. H.; LOUGH, J. M. (Eds.). Coral Bleaching Patterns: processes, causes and consequences. Berlin: Springer-Verlag, 2009. p. 83-102.

WARNER et al., 1999. Damage to photosystem II in symbiotic dinoflagellates: a determinant of coral bleaching. Proc. Nat. Acad. Sci. 96: 8007-8012.

WARNER, M. E.; FITT, W. K.; SCHMIDT, G. W. The effect of elevated temperature on the photosynthetic efficiency of zooxanthellae in hospite from four different species of reef coral: a novel approach. Plant Cell Environ., v. 19, n. 3, p. 291-299, 1996.

WARNER, M. E.; BERRY-LOWE, S. Differential xanthopyll cycling and photochemical activity in symbiotic dinoflagellates in multiple locations of three species of Caribbean coral. J. Exp. Mar. Biol. Ecol., v. 339, n. 1, p. 8695, 2006.

WINTERS, G.; HOLZMAN R.; BLEKHMAN, A.; BEER, S.; LOYA, Y. Photographic assessment of coral chlorophyll contents: Implications for ecophysiological studies and coral monitoring. J. Exp. Mar. Biol. Ecol., v. 380, n. 1-2, p. 25-35, 2009.

ZAR, J. H. Biostatistical analysis. 4th ed. New Jersey: PrenticeHall; 1999. 